\title{
Effect of health education intervention on hepatocellular carcinoma risk factor prevention in Menoufia governorate, Egypt
}

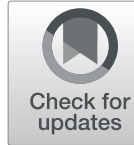

\author{
Sania Ali Yehia ${ }^{1 *}$ (D), Wesam Saber Morad', Olfat Mohamed Hendy ${ }^{2}$ and Laila Shehata Dorgham
}

\begin{abstract}
Background: Hepatocellular carcinoma is an important public health problem worldwide and in Egypt. It has a bad prognosis and few treatment options. HCV and HBV infection and exposure to pesticides and aflatoxins are major risk factors for its development, so paying more attention to prevention via raising population awareness about its risk factors may be useful in lowering HCC incidence. This study was implemented to study knowledge, attitude, and practice (KAP) of a rural community of Menoufia governorate, Egypt, pre- and post-health education intervention about HCC and prevention of its risk factors.

Results: Seroprevalence of HCV among study participants was 12.3\%, and the health education intervention about $\mathrm{HCC}$ and the prevention of its risk factors was effective in increasing the percent of pre-intervention good knowledge score groups about HCC, HBV, and HCV, pesticides, aflatoxins, and total knowledge score from 66.5\%, $88.8 \%, 83.8,41.9 \%$, and $73.7 \%$ respectively to $98.9 \%, 100 \%, 100 \%$, and $98.9 \%$ post-intervention ( $p$ value $=0.000$ for each) and was also effective in increasing the pre-intervention positive attitude score groups from 61.5 to $98.9 \%$ post-intervention. It was also effective in increasing the pre-intervention safe practice score groups of male and female study participants from $20 \%$ and $23 \%$ respectively to $94.3 \%$ and $93.1 \%$ post-intervention.

Conclusions: Health education intervention was effective in improving KAP about HCC and prevention of its risk factors and could be adopted by MOHP as a part of comprehensive program for HCC prevention in rural communities of Menoufia governorate.
\end{abstract}

Keywords: Health Education, Prevention, HCC, Risk factors, Rural, Pesticides, Aflatoxins

\section{Background}

Hepatocellular carcinoma (HCC) arises from liver cells and constitutes about $90 \%$ of all primary liver cancer types [1]. HCC is an important public health problem worldwide especially in developing countries [2]. In Egypt, HCC is an increasing problem which is the most common cancer to occur in men and the second in women [3]. HCC has a bad prognosis and few treatment options so directing efforts to its prevention is a better choice [3].

Chronic hepatitis $\mathrm{B}$ and $\mathrm{C}$ are the most important risk factors for HCC development in Egypt in addition to widely used pesticides especially in agriculture [4] and

\footnotetext{
* Correspondence: drsania_ali@yahoo.com

${ }^{1}$ Epidemiology and Preventive Medicine Department, National Liver Institute,

Gamal Abdel Nasser Street, Shebein El-Kom, Menoufia, Egypt

Full list of author information is available at the end of the article
}

consumption of aflatoxins contaminated food commodities [3]. The incidence of $\mathrm{HCC}$ can be reduced largely if people became more aware about its risk factor prevention, and this can be done via health education intervention to increase community awareness and to encourage them adopt best practices.

Studies on HCC prevention are rare [5]. Up to our knowledge, there was no study assessing knowledge, attitude, and practice of rural community of Menoufia governorate about $\mathrm{HCC}$ and prevention of its risk factors.

\section{Methods \\ Ethical considerations}

The Institutional Review Boards of both National Liver Institute Menoufia University and Ministry of Health and Population approved the study procedures. Approaches to ensure ethics were considered in the 
study regarding confidentiality and the verbal consent. The researcher introduced herself to the participants in the sample and explained the objectives of the study, to obtain their acceptance to be recruited in the study as well as to gain their cooperation.

\section{The study tools establishment}

Throughout the course of the present study, data were collected using a constructed questionnaire which was developed by the researcher based on literature review, revised by jury of professors, then tested for validity and reliability (Cronbach's alpha 0.85 ). It included four parts:

Part I: Including socio-demographic characteristics of the study participants such as age, sex, educational level, job, marital status, and their medical history.

Part II: Including questions to address participants' knowledge and attitude about hepatocellular carcinoma (HCC) and prevention of its risk factors especially viral hepatitis B and $\mathrm{C}$, aflatoxins, and pesticides.

Part III: Including questions to address participants' practice about hepatocellular carcinoma and prevention of its risk factors ( $\mathrm{HBV}$ and $\mathrm{HCV}$, aflatoxins, and pesticides).

Part IV: Including HCV status laboratory results of the study participants.

A pilot study was done on 15 participants using the constructed questionnaire to evaluate the questionnaire for clarity, time to fill the questionnaire, and applicability. These 15 participants were not included in the fullscale study. Based on the results of the pilot study, the questionnaire was modified and made ready for use.

The community-based intervention study was conducted from February 2017 till March 2019. The study was implemented in the family health unit (FHU), in a randomly selected village that was selected by a multistage random sampling technique with first stage of simple random selection of one district out of the ten districts of Menoufia governorate (Shebein El-Kom district). The second stage was simple random selection of one village out of all villages ( $N=28$ villages), and it was Kafr Tanbedy village. The third stage was a systematic random sampling of the family records, included within the (FHU), and located in Kafr Tanbedy. An equal geographical region distribution of the rural participants' family records residing at the north, south, east, and west sites of the selected village was ensured. Out of the 200 study rural participants who were contacted for participation, only 188 subjects responded out of which 179 rural participants were evaluated pre- and post-health education intervention, with a response rate of $89.5 \%$. The inclusion criteria were being a resident of Kafr Tanbedy for at least 10 years, adult with age $\geq 18$ years old, and being able to participate in an educational intervention program.

\section{Methods}

This study was done by development and implementation of health education-based intervention about HCC and prevention of its risk factors by the researcher.

\section{Development of a health education-based intervention}

The health education-based intervention was adopted from the most recent international HCC prevention guidelines and educational programs to improve participant's knowledge, attitude, and practice about HCC and its risk factors (HBV and HCV, aflatoxins, and pesticides), in which the researcher developed knowledge and practice modules regarding $\mathrm{HCC}$, viral hepatitis $\mathrm{B}$ and $\mathrm{C}$, and pesticide and aflatoxin prevention using two educational means-booklets and power point presentations.

\section{Implementation of a health education-based intervention through three phases}

1. Preparatory phase (pre-intervention family health unit visit) which included the following activities: participation agreement, discussing the objectives of the study, and collecting the selected participants' data (using the questionnaire with its four parts).

2. The implementation phase: two parts which started after 2 weeks from the pre-intervention family health unit visit in which the participants were divided into groups; ten rural participants' each group.

Part one: Health education intervention included three sessions/week. Each session is $2 \mathrm{~h}$ per day for 3 days per week for each group at the family health unit.

Part two: Serology; $3 \mathrm{ml}$ of venous blood were withdrawn from each study participant and transferred slowly into a dry sterile centrifuge tube, and the whole blood was allowed to clot at $37^{\circ} \mathrm{C}$, and then centrifuged for $10 \mathrm{~min}$ at 1500 rounds per minute; the clear supernatant serum was separated and stored in a freezer at $-80^{\circ} \mathrm{C}$ till the time of testing. Each serum sample was tested for HCV antibodies by third-generation enzyme-linked immunosorbent assay (ELIZA) using kits of MUREX-Diasorin. This was done in the National Liver Institute research laboratory at the Clinical Pathology Department.

3. The evaluation phase in which a follow-up visit was done for the study participants' at family health unit 3 months after the health education program for reassessment of HCC knowledge, attitude, and practices of these participants.

\section{Scoring system and data management Scoring of knowledge}

A score for each answer on questions of knowledge was given as follows: correct answer (2), wrong answer (1), 
and I do not know (0). HCC knowledge score ranged from 0 to $32, \mathrm{HBV}$ and $\mathrm{HCV}$ knowledge score ranged from 0 to 18 , pesticide knowledge score ranged from 0 to 18 , aflatoxin knowledge score ranged from 0 to 26 , and the total knowledge score ranged from 0 to 94 points. Good knowledge score was considered if the percentage was more than $50 \%$ and poor if the percentage was less than or equal $50 \%$.

\section{Scoring of attitude}

A score for each answer on questions of attitude was given as follows: correct answer (2), wrong answer (1), and I do not feel that (0). Attitude scores ranged from 0 to 12 points. Positive attitude score was considered if the percentage was more than $50 \%$ and negative if the percentage was less than or equal $50 \%$.

\section{Scoring of practice}

A score for each answer on questions of practice was given as follows: safe practice (2), sometimes safe practice (1), and risky practice (0). Practice score ranged from 0 to 38 and 0 to 36 points for males and females respectively. Good practice score was considered if the percentage was more than $50 \%$ and considered poor if less than or equal $50 \%$.

\section{Statistical analysis}

Data was coded and transformed into specially designed form to be suitable for computer entry process. Data was entered and analyzed by using SPSS (Statistical Package for Social Science) statistical package version 20. Graphs were done using Excel program.

Quantitative data were presented by mean $(X)$ and standard deviation (SD). Qualitative data were presented in the form of frequency distribution tables, number, and percentage. It was analyzed by chi-square $\left(\chi^{2}\right)$ test. However, if an expected value of any cell in the table was less than 5, Fisher's exact test was used (if the table was four cells) or likelihood ratio (LR) test (if the table was more than four cells). Mcnemar's test was used to measure association between paired qualitative data. Significance levels were considered at 5\% level

\section{Results}

Results showed that $45.8 \%$ of study participants were aged 18-35 years and the majority of them were married (89.9\%), and about $49.2 \%$ of them have reached the secondary education level with illiteracy of $21.8 \%$ and $55.3 \%$ (about half) of them did not work (Table 1).

The health education intervention about HCC and prevention of its risk factors was effective in decreasing the percent of poor knowledge about HCC from 33.5\% pre-intervention to $1.1 \%$ post-intervention and in increasing the percent of good knowledge about HCC
Table 1 Distribution of the study participants regarding their sociodemographic characteristics

\begin{tabular}{|c|c|c|}
\hline Socio demographic characteristics & No & Percent \\
\hline \multicolumn{3}{|l|}{ 1. Age groups } \\
\hline $18-35$ years & 82 & 45.8 \\
\hline $36-53$ years & 72 & 40.2 \\
\hline $54-70$ years & 25 & 14 \\
\hline Mean + SD (years) & \multicolumn{2}{|c|}{$(38.74+11.746)$} \\
\hline \multicolumn{3}{|l|}{ 2. Sex } \\
\hline Female & 144 & 80.4 \\
\hline Male & 35 & 19.6 \\
\hline \multicolumn{3}{|l|}{ 3. Marital status } \\
\hline Married & 161 & 89.9 \\
\hline Unmarried & 18 & 10.1 \\
\hline \multicolumn{3}{|l|}{ 4. Educational level } \\
\hline Illiterate & 39 & 21.8 \\
\hline Basic education & 12 & 6.7 \\
\hline Secondary education & 88 & 49.2 \\
\hline University and above & 40 & 22.3 \\
\hline \multicolumn{3}{|l|}{ 5. Occupation } \\
\hline Governmental & 39 & 21.8 \\
\hline Private & 18 & 10.1 \\
\hline Farmer & 10 & 5.5 \\
\hline Does not work & 99 & 55.3 \\
\hline Others* & 13 & 7.3 \\
\hline Total & 179 & 100 \\
\hline
\end{tabular}

${ }^{*}$ As dealers and free lancers

from $66.5 \%$ pre-intervention to $98.9 \%$ post-intervention, and this effect was of high statistical significance ( $p$ value $=0.000$ ). Health education was significantly effective in decreasing the percent of pre-intervention poor knowledge about $\mathrm{HBV}, \mathrm{HCV}$, pesticides, and aflatoxins and increasing the good knowledge about them postintervention $(p$ value $=0.000)($ Table 2$)$.

As regards attitude, health education intervention about HCC and its risk factor prevention was effective in decreasing percent of negative attitude from 38.5\% pre-intervention to $1.1 \%$ post-intervention and in increasing percent of good attitude from $61.5 \%$ preintervention to $98.9 \%$ post-intervention, and this effect was statistically highly significant $(p$ value $=0.000)$ (Table 3).

The health education intervention about $\mathrm{HCC}$ and prevention of its risk factors was effective in decreasing percent of risky practice of male study participants from $80 \%$ pre-intervention to $5.7 \%$ post-intervention and in increasing percent of safe practice from $20 \%$ preintervention to $94.3 \%$ post-intervention, and this effect was statistically highly significant $(p$ value $=0.000)$. Also 
Table 2 Effect of health education intervention on participant's knowledge about HCC, HBV, and HCV, pesticides, aflatoxins, and total knowledge

\begin{tabular}{|c|c|c|c|c|c|c|}
\hline \multirow[t]{2}{*}{ Knowledge items } & \multicolumn{2}{|c|}{ Pre-intervention } & \multicolumn{2}{|c|}{ Post-intervention } & \multirow[t]{2}{*}{ Mcnemar's test } & \multirow[t]{2}{*}{$p$ value } \\
\hline & No & $\%$ & No & $\%$ & & \\
\hline \multicolumn{7}{|l|}{ 1. $\mathrm{HCC}$} \\
\hline Poor (0-16) & 60 & 33.5 & 2 & 1.1 & 56.017 & 0.000 \\
\hline Good (17-32) & 119 & 66.5 & 177 & 98.9 & & \\
\hline \multicolumn{7}{|l|}{ 2. $\mathrm{HBV}$ and $\mathrm{HCV}$} \\
\hline Poor (0-9) & 20 & 11.2 & 0 & 0 & 18.050 & 0.000 \\
\hline Good (10-18) & 159 & 88.8 & 179 & 100 & & \\
\hline \multicolumn{7}{|l|}{ 3. Pesticides } \\
\hline Poor (0-9) & 29 & 16.2 & 0 & 0 & 27.034 & 0.000 \\
\hline Good (10-18) & 150 & 83.8 & 179 & 100 & & \\
\hline \multicolumn{7}{|l|}{ 4. Aflatoxins } \\
\hline Poor (0-13) & 104 & 58.1 & 2 & 1.1 & 100.010 & 0.000 \\
\hline Good (14-26) & 75 & 41.9 & 177 & 98.9 & & \\
\hline \multicolumn{7}{|l|}{ 5. Total knowledge } \\
\hline Poor (0-47) & 47 & 26.3 & 0 & 0 & 45.021 & 0.000 \\
\hline Good (48-94) & 132 & 73.7 & 179 & 100 & & \\
\hline Total & 179 & 100 & 179 & 100 & & \\
\hline
\end{tabular}

,it was effective in decreasing percent of risky practice of female study participants from $84 \%$ pre-intervention to $6.9 \%$ post-intervention and in increasing percent of safe practice from $23 \%$ pre-intervention to $93.1 \%$ postintervention, and this effect was statistically highly significant $(p$ value $=0.000)($ Table 4$)$.

Seroprevalence of HCV among study participants was $12.3 \%$ (Fig. 1). Pre-intervention, there was a statistically significant difference in HCV status of study participants in relation to their age groups ( $p$ value $=0.001)$, educational level $(p$ value $=0.009)$, and occupation $(p$ value $=$ 0.022 ) where $\mathrm{HCV}$ seropositivity was more common in the age group of 36 to 53 years (45.5\%), illiterate (45.5\%), and unemployed (31.8\%). However, there were no statistically significant difference in HCV status of study participants in relation to their sex $(p$ value $=0.33)$ and marital status $(p$ value $=0.094)($ Table 5$)$.

\section{Discussion}

HCC prevention studies are rare despite the fact that HCC incidence can be largely decreased by increasing population awareness about its known risk factors that will encourage them to adopt safer practices that may protect them from $\mathrm{HCC}$ [5].

This study was conducted on 179 rural participants to assess knowledge, attitude, and practice of the study participants pre-and post-implementation of health education intervention about hepatocellular carcinoma (HCC) and prevention of its risk factors ( $\mathrm{HBV}$ and $\mathrm{HCV}$, aflatoxins, and pesticides) and to assess the current prevalence of $\mathrm{HCV}$ among study rural participants.

In our study seroprevalence of HCV among study participants was $12.3 \%$. This was in agreement with Shiha [6] who found that (13\%) of study rural participants of El Othmaniya village in Northern Egypt were HCV seropositive. However, this was higher than Kandeel [7] who studied the data obtained from EDHS 2015 and found that the seroprevalence of $\mathrm{HCV}$ in Egypt as a whole was only $10 \%$. This can be explained by our study that was implemented in a rural area of Menoufia governorate where rural residents may have increased exposure to $\mathrm{HCV}$ infection.

Table 3 Effect of health education intervention on study participants total score of attitude towards HCC and its risk factor prevention

\begin{tabular}{|c|c|c|c|c|c|c|}
\hline \multirow[t]{2}{*}{ Attitude score groups } & \multicolumn{2}{|c|}{ Pre-intervention } & \multicolumn{2}{|c|}{ Post-intervention } & \multirow[t]{2}{*}{ Mcnemar's test } & \multirow[t]{2}{*}{$p$ value } \\
\hline & $\overline{\mathrm{No}}$ & $\%$ & $\overline{\mathrm{No}}$ & $\%$ & & \\
\hline 1. Negative (0-6) & 69 & 38.5 & 2 & 1.1 & 65.015 & 0.000 \\
\hline 2. Positive (7-12) & 110 & 61.5 & 177 & 98.9 & & \\
\hline Total & 179 & 100 & 179 & 100 & & \\
\hline
\end{tabular}


Table 4 Effect of health education intervention on study male and female participant's total score of practice about HCC and its risk factor prevention

\begin{tabular}{|c|c|c|c|c|c|c|}
\hline \multirow{2}{*}{$\begin{array}{l}\text { Practice score } \\
\text { groups }\end{array}$} & \multicolumn{2}{|c|}{ Pre-intervention } & \multicolumn{2}{|c|}{ Post-intervention } & \multirow[t]{2}{*}{ Mcnemar's test } & \multirow[t]{2}{*}{$p$ value } \\
\hline & No & $\%$ & No & $\%$ & & \\
\hline \multicolumn{7}{|l|}{ 1-Males } \\
\hline Risky (0-19) & 28 & 80 & 2 & 5.7 & 24.038 & 0.000 \\
\hline Safe (20-38) & 7 & 20 & 33 & 94.3 & & \\
\hline \multicolumn{7}{|l|}{ 2. Females } \\
\hline Risky (0-18) & 121 & 84 & 10 & 6.9 & 109.009 & 0.000 \\
\hline Safe (19-36) & 23 & 16 & 134 & 93.1 & & \\
\hline Total & 179 & 100 & 179 & 100 & & \\
\hline
\end{tabular}

In our study pre-intervention, there was a statistically highly significant difference in HCV status of study participants in relation to their age groups and about $45.5 \%$ of positive cases lie in the age group (36-53 years) while $36.4 \%$ of positive cases lie in the age group (54-70 years). Also, there was a statistically significant difference in HCV infection status of study participants in relation to their educational level and occupation where $45.5 \%$ of positive cases were illiterate and $31.8 \%$ of positive cases were unemployed. There were no statistically significant difference in HCV infection status of study participants in relation to their sex and marital status. This was in accordance with Edris [8] who studied prevalence and risk factors of HCV in Demiatte governorate, Egypt, and found no statistically significant difference between males and females regarding their $\mathrm{HCV}$ status and that unemployment, rural residence, and low educational level are risk factors for $\mathrm{HCV}$ infection. Also, Kandeel
[9] studied the risk factors of HCV infection in Egypt and found that HCV infection is more common among illiterate than those of higher educational levels. In addition, a study of El-Sayed was done in Suez Canal region in Egypt [10] and found that HCV infection is more common in unemployed and lower educational levels study participants. In addition to that, a study of Gomaa [11] found that HCV infection in Egypt is more common in older age groups than younger ones. A study of Mohlman [12] found that HCV positivity prevalence was the highest among birth cohorts before 1960 and decreased thereafter in younger age groups. Our study findings were in contrast to el-Sadawy [13] who studied HCV seroprevalence in Sharkia governorate and found that males have higher HCV seroprevalence than females. This difference can be attributed to the limitation of our study that the number of male study participants was relatively low when compared to females.

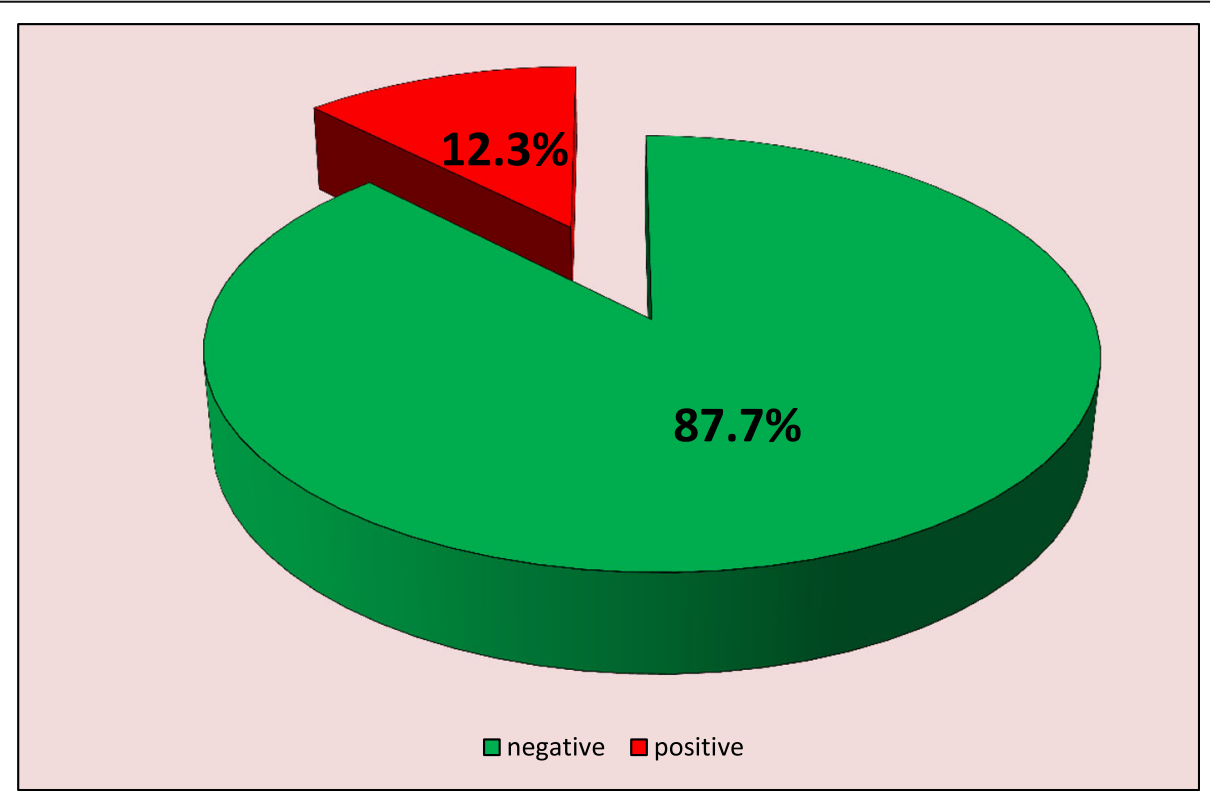

Fig. 1 Seroprevalence of HCV among study rural participants 
Table 5 The relation of study participants HCV status and their sociodemographic characteristics pre-intervention

\begin{tabular}{|c|c|c|c|c|c|c|}
\hline \multirow{3}{*}{$\begin{array}{l}\text { Sociodemographic } \\
\text { characteristics }\end{array}$} & \multicolumn{4}{|c|}{ HCV status } & \multirow{3}{*}{$\begin{array}{l}\text { Test of } \\
\text { significance }\end{array}$} & \multirow[t]{3}{*}{$p$ value } \\
\hline & \multicolumn{2}{|c|}{ Negative } & \multicolumn{2}{|c|}{ Positive } & & \\
\hline & No & $\%$ & No & $\%$ & & \\
\hline \multicolumn{7}{|l|}{ 1. Age groups } \\
\hline $18-35$ years & 78 & 49.7 & 4 & 18.1 & \multirow[t]{3}{*}{$L R=13.359$} & \multirow[t]{3}{*}{0.001} \\
\hline $36-53$ years & 62 & 39.5 & 10 & 45.5 & & \\
\hline $54-70$ years & 17 & 10.8 & 8 & 36.4 & & \\
\hline \multicolumn{7}{|l|}{ 2. Sex } \\
\hline Female & 128 & 81.5 & 16 & 72.7 & \multirow[t]{2}{*}{ Fisher's exact } & \multirow[t]{2}{*}{0.33 (NS) } \\
\hline Male & 29 & 18.5 & 6 & 27.3 & & \\
\hline \multicolumn{7}{|l|}{ 3. Marital status } \\
\hline Married & 139 & 88.5 & 22 & 100 & \multirow[t]{2}{*}{ Fisher's exact } & \multirow[t]{2}{*}{0.094 (NS) } \\
\hline Unmarried & 18 & 11.5 & 0 & 0.0 & & \\
\hline \multicolumn{7}{|l|}{ 4. Educational level } \\
\hline Illiterate & 29 & 18.5 & 10 & 45.5 & \multirow[t]{4}{*}{$L R=11.543$} & \multirow[t]{4}{*}{0.009} \\
\hline Basic & 9 & 5.7 & 3 & 13.6 & & \\
\hline Secondary & 82 & 52.2 & 6 & 27.3 & & \\
\hline University and postgraduate & 37 & 23.6 & 3 & 13.6 & & \\
\hline \multicolumn{7}{|l|}{ 5. Occupation } \\
\hline Governmental & 34 & 21.7 & 5 & 22.7 & \multirow[t]{6}{*}{$L R=11.398$} & \multirow[t]{6}{*}{0.022} \\
\hline Private & 14 & 8.9 & 4 & 18.2 & & \\
\hline Farmer & 6 & 3.8 & 4 & 18.2 & & \\
\hline Does not work & 92 & 58.6 & 7 & 31.8 & & \\
\hline Others & 11 & 7 & 2 & 9.1 & & \\
\hline Total & 157 & 100 & 22 & 100 & & \\
\hline
\end{tabular}

NS non-significant, $L R$ likelihood ratio

The health education intervention about HCC and its risk factors prevention was effective in decreasing percent of poor knowledge about HCC from $33.5 \%$ preintervention to $1.1 \%$ post-intervention and in increasing percent of good knowledge about HCC from $66.5 \%$ preintervention to $98.9 \%$ post-intervention, and this effect was statistically highly significant. Also, health education intervention was effective in decreasing percent of poor knowledge about HBV and HCV from $11.2 \%$ preintervention to $0 \%$ post-intervention and in increasing percent of good knowledge about HBV and HCV from $88.8 \%$ pre-intervention to $100 \%$ post-intervention, and this effect was statistically highly significant. It also was effective in decreasing percent of poor knowledge about pesticides from $16.2 \%$ pre-intervention to $0 \%$ postintervention and in increasing percent of good knowledge about pesticides from $83.8 \%$ pre-intervention to $100 \%$ post-intervention, and this effect was statistically highly significant. It also was effective in decreasing percent of poor knowledge about aflatoxins from 58.1\% pre-intervention to1.1\% post-intervention and in increasing percent of good knowledge score groups about aflatoxins from $41.9 \%$ pre-intervention to $98.9 \%$ postintervention, and this effect was statistically highly significant and was effective in decreasing percent of poor total knowledge about $\mathrm{HCC}$ and its risk factor prevention from $26.3 \%$ pre-intervention to $0 \%$ postintervention and in increasing percent of good total knowledge about HCC and prevention of its risk factors from $73.7 \%$ pre-intervention to $100 \%$ post-intervention, and this effect was statistically highly significant. This was in agreement with Saleh [14] who studied the effect of a pilot health education intervention about HCC prevention in Egypt and found that study participants had poor knowledge about HCC and its risk factors, and the health education intervention raised the knowledge of study participants on HCC and prevention of its risk factors.

This was also in agreement with Robotin [15] who studied the effect of community intervention for prevention of liver cancer in Australia which found that study participants have poor knowledge about HCC preintervention, that health education intervention was effective in increasing their knowledge about HCC, and 
that it is a step in the way of decreasing HCC incidence by increasing awareness about its risk factors such as hepatitis B. Our study finding was also in agreement with Juon [16] who studied the effect of health education about HCC among Asian Americans in Baltimore and found that health education was effective in raising awareness about HCC and recommend integrating health education intervention as a basic part of a comprehensive program to increase knowledge and change social norms and beliefs to promote safer practices for prevention of HCC risk factors. In addition, Shiha [6] studied the community-based intervention for $\mathrm{HCV}$ elimination in a village in Northern Egypt and found that educational intervention significantly increased knowledge and adoption of safer practices to prevent HCV transmission among study rural participants. Moreover, a study of Joun [17] found that culturally integrated liver cancer health education intervention was effective in increasing knowledge about HBV among Asian Americans. Also, a study of Farahata [18] found that knowledge, attitude, and practice of study participants in a rural community of Manshat Sultan, Menoufia governorate, regarding pesticides were improved after health education intervention.

The main limitations of our study were lack of confirmation of HCV status by PCR to study participants proven to be HCV seropositive by ELISA and also a relatively small number of male study participants when compared to females.

\section{Conclusion}

In conclusion, we found that health education intervention about HCC and prevention of its risk factors was feasible and is an effective way for raising awareness and improvement of practices of rural community in Menoufia governorate, Egypt. So, we recommend the adoption of a culturally integrated hepatocellular carcinoma risk factor prevention health education program by the Ministry of Health and Population (MOHP) and its implementation in primary health care units serving rural areas in Menoufia governorate to increase awareness about the disease and to promote safer practices to protect themselves and their families from HCC.

\section{Abbreviations \\ EDHS: Egypt Demographic Health Survey; ELISA: Enzyme-linked immunosorbent assay; FHU: Family health unit; HBV: Hepatitis B virus; HCC: Hepatocellular carcinoma; HCV: Hepatitis C virus; KAP: Knowledge, attitude, and practice; MOHP: Ministry of Health and Population; PCR: Polymerase chain reaction}

\section{Acknowledgements}

Not applicable

\section{Authors' contributions}

SA collected, analyzed, and interprited the study data and contributed in the manuscript writing. WM contributed in the manuscript writing. $\mathrm{OH}$ contributed in the manuscript writing and supervision of the laboratory work. LD was a major contributor to the manuscript writing and revising. All authors read and approved the final manuscript.

\section{Funding}

This study was partially financially supported by National Liver InstituteMenoufia University for buying HCV kits needed for the study.

\section{Availability of data and materials}

The data set of the current study is available from the corresponding author on reasonable request.

\section{Ethics approval and consent to participate}

The Institutional Review Boards of both National Liver Institute Menoufia University (IRB00003413) and Ministry of Health and Population (IRB0000687) approved the study procedures. Approaches to ensure ethics were considered in the study regarding confidentiality and the verbal consent. The researcher introduced herself to the participants in the sample and explained the objectives of the study, to obtain their acceptance to be recruited in the study as well as to gain their cooperation.

Consent for publication

Not applicable.

\section{Competing interests}

The authors declare that they have no competing interests.

\section{Author details}

${ }^{1}$ Epidemiology and Preventive Medicine Department, National Liver Institute, Gamal Abdel Nasser Street, Shebein El-Kom, Menoufia, Egypt. ${ }^{2}$ Clinical Pathology Department, National Liver Institute, Gamal Abdel Nasser Street, Shebein El-Kom, Menoufia, Egypt.

Received: 13 August 2019 Accepted: 11 December 2019

Published online: 13 January 2020

\section{References}

1. Saleh DA, Amr S, Jillson IA, Wang JH, Crowell N, Loffredo CA (2015) Preventing hepatocellular carcinoma in Egypt: results of a Pilot Health Education Intervention Study. BMC Res Notes [Internet] 8(1):384 Available from: http://www.biomedcentral.com/1756-0500/8/384. Reviewed on $6^{\text {th }}$ May, 2018

2. He W-J, Xu M-Y, Xu R-R, Zhou X-Q, Ouyang J-J, Han H et al (2013) Inpatients' knowledge about primary liver cancer and hepatitis. Asian Pacific J Cancer Prev [Internet] 14(8):4913-4918 Available from: http://koreascience. or.kr/journal/view.jsp?kj=POCPA9\&py=2013\&vnc=v14n8\&sp=4913. Reviewed on $30^{\text {th }}$ August, 2018

3. Elshamy K (2016) Challenges and future trends for cancer care in Egypt. In: Cancer Care in Countries and Societies in Transition [Internet]. Springer International Publishing, Cham, pp 117-146 Available from: http://link. springer.com/10.1007/978-3-319-22912-6_9

4. Ezzat S, Abdel-Hamid M, Abdel-Latif Eissa S, Mokhtar N, Labib AN, ElGhorory L et al (2005) Associations of pesticides, HCV, HBV, and hepatocellular carcinoma in Egypt. Int J Hyg Environ Health. 208(5):329-339

5. Ouyang J-J, He W-J, Zheng K-X, Chen G-Z (2016) Impact of an information leaflet on knowledge of hepatocellular carcinoma and hepatitis B among Chinese youth. Asian Pac J Cancer Prev [Internet] 17(1):439-443 Available from: http://www.ncbi.nlm.nih.gov/pubmed/26838252 . Reviewed on $22^{\text {th }}$ July 2018

6. Shiha G, Metwally AM, Soliman R, Elbasiony M, Mikhail NNH, Easterbrook P. An educate, test, and treat programme towards elimination of hepatitis $C$ infection in Egypt: a community-based demonstration project. Lancet Gastroenterol Hepatol [Internet]. 2018 Jul ${ }^{\text {th }} 18$; Available from: https://www. sciencedirect.com/science/article/pii/S2468125318301390. Reviewed on $16^{\text {th }}$ September 2018 .

7. Kandeel A, Genedy M, El-Refai S, Funk AL, Fontanet A, Talaat M (2017) The prevalence of hepatitis C virus infection in Egypt 2015: implications for future policy on prevention and treatment. Liver Int. 37(1):45-53

8. Edris A, Nour MO, Zedan OO, Mansour AE, Ghandour AA, Omran T (2014) Seroprevalence and risk factors for hepatitis $B$ and $C$ virus infection in Damietta Governorate, Egypt. East Mediterr Health J [Internet] 20(10):605- 
613 Available from: http://www.ncbi.nlm.nih.gov/pubmed/25356691 Reviewed on $11^{\text {th }}$ September 2018

9. Kandeel AM, Talaat M, Afifi SA, El-Sayed NM, Abdel Fadeel MA, Hajjeh RA et al (2012) Case control study to identify risk factors for acute hepatitis C virus infection in Egypt. BMC Infect Dis [Internet] 12:-294 Available from: http://www.ncbi.nlm.nih.gov/pubmed/23145873. Reviewed $5^{\text {th }}$ April 2019

10. El-Sayed H, Mehanna S, Hassan A, Sheded M, Sahmoud S, Elfiky S, et al. Risk factors of hepatitis C in the Suez Canal Region, Egypt [Internet]. Vol. 8, AfroEgypt J Infect Endem Dis. 2018. Available from: https://aeji.journals.ekb.eg/ http://mis.zu.edu.eg/ajied/home.aspx. Reviewed on $5^{\text {th }}$ April 2019.

11. Gomaa A, Allam N, Elsharkawy A, El Kassas M, Waked I (2017) Hepatitis C infection in Egypt: prevalence, impact and management strategies. Hepat Med [Internet] 9:17-25 Available from: http://www.ncbi.nlm.nih.gov/ pubmed/28553150.Reviewd on $25^{\text {th }}$ May 2018

12. Mohlman MK, Saleh DA, Ezzat S, Abdel-Hamid M, Korba B, Shetty K et al (2015) Viral transmission risk factors in an Egyptian population with high hepatitis C prevalence. BMC Public Health [Internet] 15(1):1030 Available from: http://bmcpublichealth.biomedcentral.com/articles/10.1186/s12889015-2369-y. Reviewed on $19^{\text {th }}$ Feb 2018

13. el-Sadawy M, Ragab H, el-Toukhy H, el-L E-MA, Mangoud AM, Eissa MH et al (2004) Hepatitis C virus infection at Sharkia Governorate, Egypt: seroprevalence and associated risk factors. J Egypt Soc Parasitol [Internet] 34(1 Suppl):367-384 Available from: http://www.ncbi.nlm.nih.gov/ pubmed/15124747. Reviewed $22^{\text {th }}$ May 2019

14. Saleh DA, Amr S, Jillson IA, Wang JH, Crowell N, Loffredo CA (2015) Preventing hepatocellular carcinoma in Egypt: results of a Pilot Health Education Intervention Study. BMC Res Notes [Internet] 8:384 Available from: http://www. ncbi.nlm.nih.gov/pubmed/26319021. Reviewed $18^{\text {th }}$ Feb 2018

15. Robotin MC, Kansil MQ, Porwal M, Penman AG, George J (2014) Communitybased prevention of hepatitis-B-related liver cancer: Australian insights. Bull World Health Organ [Internet] 92(5):374-379 Available from: http://www.ncbi. nIm.nih.gov/pubmed/24839327. Reviewed on $25^{\text {th }}$ Sep 2018

16. Juon H-S, Lee S, Strong C, Rimal R, Kirk GD, Bowie J (2014) Effect of a liver cancer education program on hepatitis B screening among Asian Americans in the Baltimore-Washington metropolitan area, 2009-2010. Prev Chronic Dis [Internet] 11:130258 Available from: http://www.ncbi.nlm.nih. gov/pubmed/24503341. Reviewed $22^{\text {th }}$ July 2018

17. Juon H-S, Park BJ (2013) Effectiveness of a culturally integrated liver cancer education in improving HBV knowledge among Asian Americans. Prev Med (Baltim) [Internet] 56(1):53-58 Available from: http://www.ncbi.nlm.nih.gov/ pubmed/23159302. Reviewed on $27^{\text {th }} \mathrm{Feb} 2019$

18. Taghreed M Farahata, Hala M Shaheena, Zakaria F Sanadb, Nagwa A Fraga. Knowledge, attitudes, and practices of organophosphorus pesticide exposure among women affiliated to the Manshat Sultan Family Health Center (rural area) in Menoufia governorate: an intervention study. Menoufia Med J | Publ by Wolters Kluwer Heal -Medknow [Internet]. 2016; Available from: http://www.mmj.eg.net/temp/MenoufiaMedJ291115-164 8144_002728.pdf. Reviewed on $3^{\text {th }}$ Jan 2019.

\section{Publisher's Note}

Springer Nature remains neutral with regard to jurisdictional claims in published maps and institutional affiliations.

\section{Submit your manuscript to a SpringerOpen ${ }^{\circ}$ journal and benefit from:}

- Convenient online submission

- Rigorous peer review

- Open access: articles freely available online

- High visibility within the field

- Retaining the copyright to your article

Submit your next manuscript at $\boldsymbol{\nabla}$ springeropen.com 